\title{
Implikasi Pedagogis Pada Sakramen Perjamuan Kudus Dalam Liturgi Gereja
}

\author{
Sumiyati $^{1 *}$ \& Eriyani Mendrofa ${ }^{2}$ \\ Sekolah Tinggi Teologi Kanaan Nusantara Ungaran \\ Email: ${ }^{1 *}$ sumiyatir69@gmail.com, ${ }^{2}$ mendrofaeriyani@gmail.com
}

\begin{abstract}
The Lord's Supper is one of the sacraments of the church and is an important part of the Christian liturgy. The author conducts research on the meaning of the Holy Communion so that he can find pedagogical implications in the Holy Communion. The research used is a literature analysis approach that uses various relevant literature sources. The pedagogical implications of the Lord's Supper concern the past, present and future. The meaning of the past means that the Lord's Supper is a reminder of Christ's sacrifice for believers. Today means that the Lord's Supper means sharing in enjoying the benefits of Christ's death and fellowship with the members of the body of Christ, even Christ himself. The meaning of the future means that the Holy Communion is a guarantee of enjoying the Kingdom of Heaven and the great supper in the future. The Lord's Supper is an expression of hope for His return. Christ Jesus is the sure hope. Practically speaking, Holy Communion reminds us of the importance of fellowship with fellow members of the body of Christ.
\end{abstract}

Keywords: Pedagogical, Sacrament, Communion

\begin{abstract}
ABSTRAK: Perjamuan Kudus merupakan salah satu sakramen gereja dan menjadi bagian penting dalam liturgi Kristen. Penulis melakukan penelitian terhadap makna perjamuan kudus sehingga dapat menemukan implikasi pedagogis dalam perjamuan kudus. Penelitian yang digunakan adalah pendekatan analisis pustaka yang menggunakan berbagai sumber pustaka relevan. Implikasi pedagogis Perjamuan Kudus menyangkut masa lalu, masa kini dan masa yang akan datang. Makna masa lalu berarti bahwa Perjamuan Kudus merupakan peringatan pengorbanan Kristus bagi orang percaya. Masa kini berarti bahwa Perjamuan Kudus memiliki makna keikutsertaan menikmati keuntungan kematian Kristus serta persekutuan dengan anggota tubuh Kristus, bahkan Kristus sendiri. Makna masa yang akan datang berarti bahwa Perjamuan Kudus menjadi jaminan menikmati Kerajaan Sorga dan perjamuan agung di masa yang akan datang. Perjamuan Kudus merupakan perwujudan pengharapan akan kedatangan-Nya kembali. Kristus Yesus adalah pengharapan yang pasti. Secara praktis, Perjamuan Kudus mengingatkan tentang pentingnya persekutuan dengan sesama anggota tubuh Kristus.
\end{abstract}

Kata-kata kunci: Pedagogis, Sakramen, Perjamuan Kudus

Article History: Submitted: 22 September 2020 Revised: 28 Januari $2021 \quad$ Published: 31 Januari 2021

\section{PENDAHULUAN}

Gereja sebagai persekutuan orang kudus, diambil dari istilah Yunani, Ekklesia dalam Perjanjian Baru yang berarti umat atau jemaat (Rm. 16:5; Ef. 1: 22-23; I Kor. 12:13-14; Gal. 1:1-2 dsb.). Gereja bukanlah kumpulan orang yang suci sempurna, tanpa cela, tetapi kumpulan orang berdosa yang memperoleh anugerah Allah untuk dikuduskan dan yang juga dipanggil supaya menguduskan diri (Silitonga, Natonis, \& Darmawan, 2020; Simpson, 1984). Oleh sebab itu, orang Kristen hidup penuh dengan pergumulan antara manusia lama yang dikuasai oleh dosa dengan manusia yang baru yang dikuasai Roh Kudus (II Kor. 5:17). Menurut Hadiwijono (2001, p. 157) orang percaya akan menghadapi yang namanya pergumulan, oleh karena itu dibutuhkan iman yang kuat dan kesiapan menghadapi tipu muslihat Iblis. Allah memberikan firman-Nya serta pelayanan sakramen sebagai sarana untuk menguatkan iman. Sakramen menjadi satu tanda lahiriah yang sakral, menjadi salah satu bentuk pengejawantahan keyakinan iman dalam tindakan-tindakan lahiriah. 
Masing-masing denomisai gereja memiliki doktrin yang menjadi asas dan pengajarannya, termasuk juga doktrin tentang sakramen yang menjadi doktrin fundamental gereja. Sebagai perkumpulan orang beriman, di dalam gereja terdapat ritus-ritus sakramen. Dalam dokumen Konferensi Wali Gereja Indonesia (1996, p. 400), dituliskan bahwa dalam sebuah sakramen rahmat Allah dengan konkret diutarakan menggunakan tanda badaniah maupun simbol. Tanda-tanda tersebut memproklamirkan apa saja yang diyakini dan diterima secara rohani ke dalam bentuk tindakan lahiriah yang nyata.

Istilah sakramen berasal dari kata sacramentum yang memiliki makna kudus atau suci. Dengan demikian, kata sakramen mengacu pada penyucian (Martasudjita, 2003, pp. 61-67; Naat, 2020; Pattiasina, 2019; Tuela, 2014). Hadiwijono (2010, p. 424) mengungkapkan bahwa istilah sakramen tidak berasal dari istilah dalam Alkitab, tetapi berasal dari tradisi Romawi, yaitu dari kata sacramentum. Dalam sejarah Gereja, sakramen yang dilaksanakan, tidak hanya terbentuk dari teori, melainkan dimulai sebagai praktik. Pada masa gereja mula-mula terdapat berbagai sakramen yang dianggap penting, mutlak, dan menjadi salah satu bentuk pelaksanaan hidup gereja (Indonesia, 1996, p. 398). Hadiwijoyo (2010, p. 418) berpendapat bahwa gereja memiliki peran sebagai sebagai alat keselamatan yang dipakai Allah membawa jiwa terlibat dalam pesekutuan Tubuh Kristus. Ia melanjutkan penjelasannya dengan mengatakan bahwa gereja yang adalah kesatuan orang-orang beriman merupakan alat keselamatan yang juga berfungsi membenahi kelakuan serta mendidik umat Allah. Dalam gereja mula-mula, sakramen adalah hal-hal rahasia, berkaitan tentang Allah serta penyataan-Nya dalam peribadatan dan hal lainnya.

Sakramen-sakramen dalam Gereja Protestan datang dari Yesus Kristus yang kemudian terus dilaksanakan dalam gereja melalui pimpinan $\mathrm{Roh} \mathrm{Ku}$ dus. Tujuan sakramen adalah untuk mengingatkan kasih Allah yang menguduskan manusia sehingga orang percaya membangun Tubuh Kristus dan mempersembahkan ibadah yang berkenan kepada Allah (Naat,
2020; Pakpahan, 2014, p. 48). Terdapat dua unsur dari sakramen, yaitu pertama, forma atau perkataan yang menggambarkan peristiwa ilahi. Kedua adalah materia berupa tindakan tertentu. "Perkataan" dan "tindakan"; inilah cara yang mana sakramen diungkapkan. Karena sakramen diyakini sebagai sebuah tanda dan sarana persatuan yang mesra dengan Allah dan kesatuan tubuh Kristus, maka sakramen dirayakan oleh dan di dalam gereja (Prasetya, 1999, p. 133). Martasudjita (2003, p. 67) kemudian memandang sakramen sebagai sebuah ritus Kristen demi mendatangkan dan menyalurkan rahmat Allah. Soedarmo (1989, p. 224) mengartikan sakramen sebagai kesepakatan manusia dengan Tuhan Allah. Oleh sebab itu, dengan mengikuti sakramen orang percaya menyatakan sumpah kesetiaan kepada Tuhan Yesus Kristus. Sakramen ditentukan Allah sebagai tanda dan meterai untuk menjelaskan janji Allah dan untuk meneguhkan iman (Soedarmo, 1989, pp. 224225). Sakramen dapat dilihat dalam liturgi gereja sehingga manusia dapat membangun penghayatan terhadap rahmat Allah yang agung. Dalam sakramen keagungan Allah kemudian dihayati oleh orang percaya sehingga iman menjadi terbangun dan bertumbuh menjadi manusia Kristen yang dewasa.

Dalam penulisan ini penulis membahas tentang sakramen Perjamuan Kudus, yang diakui dan diterima oleh gereja dalam denominasi apapun. Walaupun dalam setiap denominasi gereja Perjamuan $\mathrm{Ku}$ dus diajarkan dan dilaksanakan dalam bingkai dogmatika yang berbeda-beda. Jikalau gereja melakukan Perjamuan Kudus, hal itu dilakukan karena Tuhan Yesus Kristus memerintahkan untuk melakukan Perjamuan Kudus sebagaimana dituliskan dalam Lukas 22:19 dan I Korintus 11:25. Konsep dasar Perjamuan Kudus sejatinya bukan sebuah peraturan baru, melainkan konsepnya telah ada sejak zaman Perjanjian Lama.

Bagi setiap orang Kristen, Perjamuan Kudus bukan merupakan sesuatu yang asing sebab di beberapa gereja, sakramen Perjamuan Kudus dilakukan pada minggu pertama setiap bulan. Di beberapa denominasi gereja, bila seorang Kristen telah mengaku 
percaya (sidi) atau sudah mengikuti baptisan, sudah diijinkan mengikuti untuk Perjamuan Kudus. Orang percaya mengikuti Perjamuan Kudus karena upacara ini merupakan perintah Yesus bagi umat percaya. Tetapi Perjamuan Kudus umumnya dimaknai sebagai sekadar satu ritual keharusan dalam kekristenan yang tidak memberi makna dan pengalaman rohani. Sakramen Perjamuan Kudus pada masa kini kemudian menghadapi bahaya degradasi, misalnya cara pelaksanaan dan konsep yang keliru. Hal ini dapat berdampak pada kehidupan jemaat, yang mengambil bagian dalam Perjamuan Kudus namun tidak bertumbuh dalam iman. Oleh sebab itu, penulis ingin memberikan kontribusi dengan meneliti implikasi pedagogis sakramen Perjamuan Kudus.

Selain itu, dari beberapa penelitian sebelumnya yang telah meneliti tentang Perjamuan Kudus, fokus penelitiannya pada aspek teologis. Penelitian Tuela (2014) yang meneliti Perjamuan Kudus menurut Yohanes Calvin. Kemudian penelitian Pattiasina (2019) yang meneliti tentang Perjamuan Kudus dalam kehidupan bergereja di Gereja Protestan Maluku. Sementara penelitian Panjaitan (2013) melihat Perjamuan Kudus dalam kerangka teologi ingatan untuk menjadi dasar dalam resolusi konflik. Sementara menurut penulis, sakramen Perjamuan Kudus memiliki sisi lain yang perlu diteliti. Oleh sebab itu, penulis melakukan penelitian terhadap implikasi pedagogis dalam Perjamuan Kudus. Rumusan masalah penelitian ini adalah bagaimana implikasi pedagogis sakramen Perjamuan Kudus?

\section{METODE}

Penulis menggunakan penelitian kualitatif dengan pendekatan analisis literatur. Darmawan dan Asrinigsari (2018) maupun (2016) mengungkapkan bahwa pendekatan analisis literatur dapat digunakan untuk penelitian dalam lingkup teologi. Demikian pula dijelaskan oleh Zaluchu (2020) bahwa penelitian kualitatif yang meneliti teks maupun literatur dilakukan untuk memahami makna yang mendalam.

Dalam penelitian ini, penulis melakukan analisis terhadap berbagai literatur teologi yang terkait dengan Perjamuan Kudus. Sumber-sumber literatur dari buku dan jurnal menjadi rujukan utama. Sesuai dengan pendapat Smith (2016) maupun (2019) bahwa penelitian dengan pendekatan analisis literatur membutuhkan sumber-sumber pustaka yang relevan. Literatur-literatur yang menjadi sumber pustaka utama penelitian ini adalah tulisan Abineno (1981) yang cukup klasik tetapi memberi penjelasan penting, Hadiwijono (2001), Heyer (1997), dan Martasudjita (2003) menjadi sumber penting dalam penelitian ini. Kemudian jurnal-jurnal karya Pakpahan (2013, 2014), Tuela (2014), Pattiasina (2019), dan Panjaitan (2013) yang meneliti dan membahas secara teologis dan praktis tentang Perjamuan Kudus. Kemudian beberapa teks Alkitab yang berbicara tentang Perjamuan Kudus juga menjadi sumber penting yang kemudian dianalisis untuk memperoleh maknanya. Hasil analisis kemudian disajikan secara deskriptif tematis.

\section{HASIL DAN PEMBAHASAN}

\section{Hakikat Perjamuan Kudus}

Sebelum Yesus ditangkap, Ia mengadakan Perjamuan Kudus bersama dengan murid-murid-Nya dan Yesus kemudian menetapkan Perjamuan Kudus sebagai sebuah kegiatan adalah harus dilakukan sebagai peringatan akan Kristus (Tuela, 2014). Hal ini dicatat dalam Matius 26:26, Markus 14:22, Lukas 22:14, dan I Korintus 11:23. Pattiasina (2019) menjelaskan bahwa Perjamuan Kudus yang diadakan Yesus memiliki hubungan berhubungan dengan Pesakh (Indonesia: Paskah) orang Yahudi. Pesakh artinya berlalu atau melewati/lewat. Berdasarkan Keluaran 12:13, Abineno (1981, pp. 137-138) menjelaskan bahwa Allah berjanji, bangsa Israel akan dibebaskan dari kematian ketika Allah menjatuhkan hukumanNya bagi orang Mesir. Pada malam itu pintu-pintu dengan tanda darah anak domba Paskah tidak akan mengalami kebinasaan. Peristiwa Paskah ini kemudian menyatakan perjanjian Allah dengan Israel yang memberikan kelepasan dari perbudakan di Mesir.

Dalam tradisi Yahudi pada masa Perjanjian Lama, dalam masyarakat perjamuan memiliki fungsi 
sosial. Pesta perjamuan pada masa Perjanjian Lama tidak hanya dilakukan untuk hal-hal yang membahagiakan, seperti kelahiran, sunat, pertunangan, pernikahan (Ul. 26:141; I Sam. 1:7,18; 2:34), tetapi dilaksanakan juga ketika ada perkabungan, contohnya mereka "memecahkan roti tanda berkabung" untuk memberikan penghiburan bagi orang yang sedang berduka; kemudian terdapat "cawan penghiburan" yang diberikan kepada orang yang berkabung untuk memberikan penghiburan (Yer. 16:7). Dalam pesta perjamuan tersebut orang tertawa tetapi juga menangis. Melalui perjamuan, mereka membentuk sebuah persekutuan yang kuat baik saat berduka maupun senang (Barth \& Frommel, 1998, p. 245). Dari hal ini tampak jika dalam Perjanjian Lama, istilah Perjamuan Kudus tidak dikenal, tetapi terdapat perjamuan bersama yang disertai pemberian berupa kurban atau persembahan untuk Allah (Ul. 12:7). Perjamuan ini diadakan menjadi meterai perjanjian antara Yahweh dengan umat-Nya (Kel. 24:11; Mzm. 50:5). Dengan demikian ada dua fungsi perjamuan adalah upacara kepada Yahweh dan perjanjian sesama umat.

Perjamuan Paskah juga dikenal Bangsa Israel, yang mana dilaksanakan dengan mempersembahkan seekor domba yang tidak bercacat menjadi korban bakaran kepada Allah. Mereka kemudian memercikkan di ambang pintu rumahnya, darah kurban yang disembelih. Hal ini sama seperti ketika Allah membebaskan mereka dari tanah Mesir dan Allah menetapkan perjamuan ini untuk diperingati setiap tahunnya. Bavink menjelaskan bahwa menurut Keluaran 12:4, perjamuan memiliki makna bahwa umat Allah melakukan ziarah dan menghayati pertolongan Tuhan dalam peristiwa di Mesir, dan menjadi pengharapan dalam menantikan pelepasan Tuhan di masa yang akan datang (Bavink, 1990, p. 20). Jadi makna perayaan Paskah dimaksudkan menjadi perayaan peringatan di mana Allah membebaskan umat-Nya dari perbudakan. Dengan mengingatkan karya Allah membebaskan bangsa Israel, ada tuntutan untuk menyadari rahmat Allah. Dalam perayaan tersebut, orang Israel tidak diperkenankan menggunakan ragi dalam pembuatan Roti Paskah (Kel. 12:8).
Orang Israel harus memperlakukan Roti Paskah dengan rasa hormat, sehingga Roti Paskah tidak dipotong dengan pisau, melainkan dengan disobek atau dipotong menggunakan tangan. Roti Paskah terdiri dari tiga buah roti tidak beragi dan dimasukkan dalam kantong rangkap empat. Ketiga lapisan roti tersebut melambangkan tiga kelas masyarakat Yahudi, yaitu Imam, Lewi dan orang-orang Israel. Ketika dilakukan pembacaan kisah keluarnya orang Israel dari Mesir, maka mereka mengeluarkan roti yang di tengah kemudian diangkat dan dipecahkan menjadi dua. Yang setengah bagian kemudian disembunyikan oleh pemimpin perjamuan. Hal ini disebut juga sebagai "afikomen" yang berarti yang datang kemudian dan roti ini dimakan sebagai makanan menjadi makanan penutup. "Afikomen" secara rohani melambangkan kedatangan Mesias kedua kali ("Roti Paskah," 2012, p. 1).

Tradisi Perjanjian Lama tersebut kemudian dilanjutkan dalam masa Perjanjian Baru. Dalam Perjanjian Baru tampak Yesus beserta murid-murid menikmati perjamuan malam sebagai bentuk perayaan Paskah. Dalam peristiwa tersebut, Yesus memimpin perjamuan tersebut. Kata-kata Yesus tercantum di dalam 1 Korintus 11:24-25. Berdasarkan perkataan Yesus inilah, gereja mula-mula melaksanakan sakramen Perjamuan Kudus sebagai pengingat akan perbuatan Allah melalui Yesus (Tuela, 2014).

Beberapa gereja seperti gereja Katolik, Komuni Anglikan, Gereja Ortodoks Timur, dan Gereja Lutheran istilah yang digunakan adalah ekaristi (Yunani: $\varepsilon v \chi \alpha \rho \imath \sigma \tau \omega)$. Kata $\varepsilon v \chi \alpha \rho \imath \sigma \tau \omega$ memiliki arti berterima kasih atau bersyukur. Sementara gerejagereja Protestan di Indonesia secara umum menggunakan istilah Perjamuan Kudus (Heyer, 1997, p. 231). Dalam konteks Perjanjian Baru, Perjamuan Kudus merupakan perjanjian dalam bentuk jemuan yang mana terjadi di antara Allah dan umat percaya di Golgota. Dalam peristiwa itu, Kristus adalah anak Domba Paskah yang kudus dan tak bercela, yang pengorbanan-Nya terjadi 1 kali untuk kekekalan (I Kor. 5:7). Melalui Perjamuan Kudus, peristiwa tersebut kemudian selalu diingat, disyukuri dan diberitakan. Niftrik 
dan Boland (1978) mengungkapkan bahwa orang percaya disatukan dengan Kristus dalam kematian dan kebangkitan-Nya ketika menerima roti dan anggur. Hal ini memampukan umat Allah mengambil bagian dalam hal yang dilakukan Yesus untuk umat manusia.

\section{Empat Teori Besar Doktrin Perjamuan Kudus}

Teori Transubstansiasi (Perubahan Materi). Doktrin ini dianut oleh gereja Katolik. Williamson (2004, p. 346) mengutip pendapat Hodge (1958, p. 359) menjelaskan bahwa doktrin transubstansiasi mengajarkan jika seluruh subtansi roti diubah menjadi tubuh dalam arti hurufiah, dari Kristus. Oleh sebab itu, hanya penampakan dan properti yang terasa dari roti dan anggur itu yang masih tersisa, tetapi subtansisubtansi yang ada benar-benar merupakan tubuh dan darah sejati, jiwa dan keilahian, dari Tuhan. Setelah diucapkan berkat maka roti dan anggur yang adalah materi berubah menjadi tubuh serta darah Tuhan, walau materi tidak berubah setelah pemberkatan. Meski demikian, jemaat-jemaat gereja Katolik meyakini jika roti dan anggur adalah bentuk materi dari tubuh dan darah Tuhan.

Teori Konsubtansiasi (Penyatuan Materi Martin Luther). Luther menolak ajaran Katolik tentang transubstansiasi, tetapi Luther tidak menolak bahwa terdapat kehadiran tubuh dan darah Kristus dalam roti dan anggur. Abineno (1990, p. 21) menjelaskan bahwa ajaran Luther ini disebut dengan konsubstansiasi. Dalam pandangan ini tidak ada perubahan dari materi roti anggur sebagaimana teori transubstansiasi, melainkan tubuh dan darah Kristus mendiaminya sehingga terdapat dua substansi dalam roti dan anggur tersebut. Perjamuan Kudus ditetapkan oleh Kristus sendiri. Roti dan dan anggur dimakan dan diminum atas dasar firman. Firman inilah yang membuat roti dan anggur menjadi tidak biasa. Ini yang menjadi dasar pandangan Luther.

Teori Lambang atau Simbolis. Teori ini adalah pandangan Zwingli. Roti dan air anggur adalah lambang tubuh dan darah Kristus. Semuanya bermakna secara rohani (Abineno, 1990, p. 64). Hal yang terpenting bagi Zwingli adalah "mengingat"; upacara ini sebagai pengingat karya Kristus - kematian dan kebangkitan-Nya.

Teori John Calvin. Dalam pandangan Calvin, Perjamuan Kudus merupakan peringatan atas kematian Kristus. Pandangan Calvin sama seperti pandangan Zwingli, yang menolak kehadiran fisik Kristus dalam roti dan anggur Perjamuan Kudus. Meski demikian, Calvin memiliki kesamaan pandangan dengan Luther bahwa Kristus benar-benar hadir secara rohani dalam Perjamuan Kudus, bukan secara fisik sebagaimana pandangan Katolik (Abineno, 1990, p. 123; Tuela, 2014). Kristus hadir bukan di dalam roti dan anggur, tetapi hadir secara rohani melalui Roh Kudus di tengah-tengah umat-Nya yang sedang melakukan Perjamuan Kudus sehingga tanpa karya Roh Kudus, sakramen Perjamuan Kudus akan menjadi siasia.

\section{Implikasi Pedagosis Perjamuan Kudus}

Secara etimologi, kata pedagogi berasal dari bahasa Yunani "paedos" (anak laki-laki) dan "agogos" (menghantar atau membimbing). Pedagogik juga dipahami sebagai seorang ahli yang memberikan bimbingan pada anak untuk tujuan tertentu (Mary \& Darmawan, 2018; Purwanto, 2000; Rizky, 2016). Karena tujuan pendidikan bukan hanya mentransformasikan pengetahuan, melainkan juga pengembangan kepribadian (Putry, Darmawan, \& Sujoko, 2020). Dalam peristiwa Perjamuan Kudus dapat diambil beberapa nilai pedagogik yang dapat diambil. Penulis yakin, bahwa sebagai Guru Agung, Yesus Kristus memiliki tujuan tertentu ketika memberikan perintah untuk melaksanakan secara berkelanjutan Perjamuan Kudus tersebut. Karena mendidik adalah upaya, sadar dan sengaja, diorientasikan ke waktu yang akan datang (Tety \& Wiraatmadja, 2017).

Terdapat empat pembahasan mengenai Perjamuan Kudus dalam Alkitab yaitu Matius 26:26-29; Markus 14:22-25; Lukas 22:15-20 dan I Korintus 11:23-25. Dalam pembahasan akan terlihat bahwa makna Perjamuan Kudus berkaitan dengan masa lalu, kini, dan yang akan datang, dan makna praktis. 


\section{Makna Masa Lalu}

Perjamuan Kudus merupakan sebuah peringatan karya pengorbanan Kristus bagi orang percaya. Dalam I Korintus 11:23-24 Rasul Paulus membicarakan tentang Penetapan Perjamuan Kudus. Kata "kuteruskan" dan "telah kuterima", adalah ungkapan yang umum dalam pengajaran kekristenan (bd. 11:2; 15:3), (Guthrie, 2007, p. 503). Di sini Paulus menyampaikan kepada jemaat Tuhan di Korintus bahwa Perjamuan Kudus adalah perayaan yang diperintahkan secara lisan oleh Tuhan Yesus sendiri untuk dilaksanakan. Kemudian beralih kepada kata perbuatlah ini dan peringatan dalam ayat 24. Kata $\mathrm{Yu}-$ nani untuk perbuatlah ini hanya dapat berarti: 'lakukanlah perbuatan ini', bukan 'korbankanlah ini' Lagi kata Yunani bagi menjadi peringatan akan Aku tak mengandung arti 'ingatkanlah Allah akan daku' melainkan 'ingatkanlah dirimu sendiri akan kematian yang Aku (tekanan) untuk mendapatkan keselamatanmu (Guthrie, 2007, p. 503).

Perintah untuk terus mengulang Perjamuan Kudus dimaksudkan untuk terus memperingati apa yang dikerjakan Kristus di atas kayu salib untuk keselamatan manusia. Melalui karya Kristus di atas kayu salib manusia berdosa beroleh pengampunan dan penebusan. Pintu pengampunan dosa dibuka oleh Tuhan melalui pengorbanan Kristus di atas kayu salib. Kristus berfungsi sebagai imam besar dan sekaligus membawa darah-Nya sendiri sebagai korban pendamaian (Ibr. 9:11). Pengorbanan Kristus terus diingat sebagai bentuk pengucapan syukur (Yun: eucharistia) atas anugerah keselamatan Allah melalui karya Kristus di kayu salib (Mat. 26:27; Mrk. 14:23, Luk. 22:19), (Stamps, 1984, p. 1900). Pengampunan dosa membawa keselamatan bagi yang percaya kepada-Nya dan menantikan-Nya, anugerah termulia yang sudah sepantasnya selalu disyukuri.

Perjamuan Kudus tampak menjadi sebuah ziarah ke masa lalu untuk mengingat karya Allah dalam Kristus Yesus. Pola ini sebenarnya menjadi penekanan dalam Perjanjian Lama. Dalam Perjanjian Lama, terkait dengan syema, bangsa Israel diberi perintah untuk terus mengajarkan berulang-ulang agar me- ngingat karya Allah (Darmawan, 2019b; Rantesalu, 2018). Demikian pula sakramen Perjamuan Kudus membawa jemaat pada ingatan akan karya penyelamataan Kristus bagi manusia yang berdosa. Hal ini menunjukkan bahwa Perjamuan Kudus memiliki penekanan pedagogis dalam pembinaan jemaat. Menurut Groome (2011), pendidikan merupakan sebuah ziarah untuk merenungkan karya Allah pada manusia. Karena Perjamuan Kudus adalah sebuah ziarah masa lalu maka, sakramen memiliki aspek pedagogis yang berkaitan dengan makna masa lalu.

\section{Makna Masa Kini}

Pertama, Perjamuan Kudus memiliki makna persekutuan (Yun: Koinonia). Melalui Perjamuan Kudus orang percaya turut menikmati keuntungan dari kematian Kristus, bahkan turut serta dalam persekutuan baik dengan anggota tubuh Kristus dan bahkan Kristus itu sendiri (Stamps, 1984, p. 1900). Dalam Roma 6:6, Paulus menggunakan dua istilah yaitu 1) Manusia lama yang merujuk kepada manusia yang belum diperbaharui dan kehidupan dalam dosa. Melalui Pejamuan Kudus orang percaya diingatkan secara berulang-ulang bahwa telah disalibkan atau dimatikan manusia lama tersebut dan mereka menerima kehidupan yang baru. Secara pedagogis, Perjamuan Kudus yang dilakukan berulang-ulang sama seperti pembelajaran memorisasi yang mengingat karya Allah. Menurut Darmawan (2019b) melalui pembelajaran memorisasi, orang akan dapat mengingat pesan yang disampaikan dan karena secara terus menerus maka akan mendorong timbulnya pemahaman yang dapat mendorong terjadinya perubahan hidup. Pakpahan (2013) mengungkapkan bahwa sakramen Perjamuan Kudus sangat kental dengan penekanan pada ingatan akan karya Allah; 2) Tubuh dosa. Frasa ini mengacu pada keinginan dosa dalam tubuh manusia. Hidup dan tubuh tidak lagi dikuasai cara hidup lama (I Kor. 5:17). Melalui Perjamuan Kudus, orang percaya diingatkan akan kasih Allah pada manusia. Secara pedagogis, sakramen Perjamuan Kudus membimbing orang percaya pada kesadaran akan kasih dan anugerah Allah. 
Kedua, Perjamuan Kudus juga sebuah tanda memproklamirkan perjanjian yang baru kepada Allah. Dengan karya Agung Kristus setiap orang yang percaya dibenarkan oleh iman kepada Kristus (Mawikere, 2017). Melalui pelaksanaan Perjamuan Kudus, orang percaya diingatkan akan panggilan untuk setia kepada-Nya. Hal ini sejalan dengan Roma 3:22-24. Kata pisteos Iesou Khristou pada ayat Roma 3:22 diterjemahkan dengan "iman dalam Yesus Kristus" dan pisteos Iesou pada Roma 3:26 diterjemahkan dengan "percaya kepada Yesus". Keduanya memiliki makna yang mirip. Terjemahan Baru Lembaga Alkitab Indonesia melihat ini sebagai genetifobjek (Santoso, 2011, p. 177). Namun terjemahan NRSV memberikan catatan kaki pada Roma 3:22 yang mengindikasikan, bahwa frasa ini bukan hanya dapat diterjemahkan dengan 'iman kepada Kristus' (Santoso, 2018, p. 9). Jika dilihat sebagai genetifsubjek, maka kata pistis tidak diterjemahkan dengan "iman" melainkan "kesetiaan". Sebagai genetif-subjek, frasa ini dapat diterjemahkan dengan "kesetiaan Kristus". Frasa ini memiliki makna "kesetiaan" yang berasal dari kesetiaannya Kristus (Santoso, 2018, p. 9). Sehingga dapat dikatakan, setiap orang yang percaya dibenarkan oleh kesetiaan Kristus dan orang dibenarkan karena iman kepada Kristus. Dari analisis frasa tersebut diperoleh dua hal pokok dalam ajaran pembenaran Allah bagi manusia, yaitu pembenaran manusia didapat melalui kesetiaan Kristus dan melalui iman kepada Kristus.

Martin Luther mencanangkan reformasi berdasarkan teologi Paulus tadi, bahwa manusia menjadi selamat bukan melalui usaha dan jerih payahnya, melainkan itu hanya merupakan anugerah Allah. Untuk itu dia mencanangkan ajaran Sola Gratia. Lebih lanjut, pembenaran tersebut terjadi melalui dua hal: kesetiaan Kristus, yang kemudian oleh Marthin Luther disebut dengan ajaran Solus Christus dan iman kepada Kristus, yang kemudian disebut dengan ajaran sola fide (Santoso, 2018, p. 13). Orang percaya diselamatkan sola gratia, hanya oleh anugerah Allah (Kadarmanto, 2018; Katarina \& Darmawan, 2019; Susanti, 2017). Orang percaya sekali lagi dihadapkan pada pengorbanan Kristus yang karena kesetiaan-Nya menganugerahi manusia pembenaran oleh iman kepada Kristus yang membawa kepada keselamatan. Kematian Kristus menjadi motivasi tertinggi untuk meninggalkan dosa. Dengan demikian, Perjamuan Kudus menjadi simbol nyata memproklamasikan kembali ketuhanan Kristus yang telah menganugerahkan pembenaran, melalui iman dan penyerahan diri secara total kepada Kristus, dan mengambil komitmen tinggal setia untuk melawan dosa.

Ketiga, Pemberitaan Injil juga merupakan makna Perjamuan Kudus di masa sekarang. Kaum Injili menurut Objantoro (2017) sangat menekankan pada pemberitaan Injil dalam berbagai kondisi. Sebagai orang-orang yang sudah dibenarkan dan diselamatkan diberikan Amanat Agung untuk memberitakan kabar baik, anugerah keselamatan di dalam Kristus. Tujuan pemberitaan Injil adalah memuridkan mereka yang akan menaati semua perintah Kristus (Darmawan, 2017, 2019a). Dalam I Korintus 11:26, Rasul Paulus menegaskan makna pelaksanaan Perjamuan Kudus adalah pewartaan secara berulang (ditunjukkan dengan kata setiap kali) peristiwa kematian Yesus yang membawa anugerah keselamatan bagi dunia.

\section{Makna Masa Yang Akan Datang}

Perjamuan Kudus menjadi jaminan menikmati Kerajaan Sorga dan perjamuan agung di masa yang akan datang (Mat. 8:11, Mrk. 14:25, Luk. 13:29). Perjamuan Kudus merupakan perwujudan pengharapan akan kedatangan-Nya kembali. Kristus Yesus adalah pengharapan yang pasti. Ibrani 6:20 menegaskan bahwa Yesus sangat memenuhi syarat sebagai pemberi harapan yang pasti kepada manusia baik di dunia ini maupun pada kekekalan yang akan datang. Karena Yesus telah membuka jalan terwujudnya kembali hubungan yang harmonis antara Allah dan manusia. Yesus telah mati sebagai tebusan sekaligus juga menjadi imam yang melaksanakan penebusan di hadapan Allah. Kematian Yesus juga tidak abadi, hanya tiga hari saja, setelah itu Ia bangkit sebagai pemenang untuk selama-lamanya. Tuhan Yesus 
pasti akan datang kembali, sebagaimana dituliskan dalam Alkitab. Brill (2003, p. 303) menerangkan bahwa, kedatangan kembali Kristus merupakan pengharapan bagi umat Allah (Tit. 2:13). Sakramen Perjamuan Kudus menjadi momen untuk memberitakan pengharapan di dalam Kristus. Dengan demikian secara pedagogis, Perjamuan Kudus menjadi wadah pengajaran dan pemberitaan pengharapan di dalam Kristus.

\section{Makna Praktis Perjamuan Kudus}

Secara praktis, Perjamuan Kudus mengingatkan tentang pentingnya persekutuan dengan sesama anggota tubuh Kristus. Persekutuan berfungsi membawa jemaat menuju kesatuan sebagai anggota tubuh Kristus dan dalam persekutuan tersebut, jemaat dibawa untuk mengingat karya Kristus di kayu salib melalui Perjamuan Kudus (Pakpahan, 2013, p. 53). Perjamuan Kudus dilakukan secara bersama-sama dengan anggota tubuh Kristus yang lain. Dalam persekutuan itu, jemaat bersama-sama melihat, menyaksikan, dan mengalami sakramen yang suci (Naat, 2020). Perjamuan Kudus tidak dapat dilakukan seorang diri karena akan mengubah makna Perjamuan Kudus itu sendiri. Perjamuan Kudus menurut Naat (2020, p. 8), mengandung makna rohani tentang persekutuan dalam kematian dan kebangkitan Tuhan melalui Perjamuan Kudus. Dengan persekutuan setiap orang dapat belajar bahwa tidak semua orang dapat menjadi seperti yang diharapkan. Seseorang bahkan tidak akan pernah dapat mengubah orang lain seperti kehendak hatinya. Namun dalam persekutuan diajarkan untuk saling menerima satu dengan yang lain. Perjamuan Kudus dalam persekutuan ini juga memberi dorongan pada terjadinya rekonsiliasi bagi sesama anggota tubuh Kristus yang berkonflik (Panjaitan, 2013). Dalam analisis Rumbi (2019) tentang manajemen konflik jemaat mula-mula, tampaknya persekutuan menjadi bagian penting dalam menghadapi konflik sehingga terbangun persekutuan antar orang percaya. Tidak dapat dipungkiri, Perjamuan Kudus dilakukan bersama-sama orang percaya pada masa itu, dan menjadi pengingat kasih dan pendamaian Allah.

\section{Introspeksi Syarat Mengikuti Perjamuan Kudus}

Orang-orang yang menerima Kristus yang akan menikmati perjamuan (Naat, 2020). Orangorang yang tidak dibaptis belum bisa terlibat dalam sakramen ini. Tidak diperkenankan seorangpun mengikuti perjamuan dengan sikap enteng seolaholah dengan bersantai sambil meminum teh di rumah seseorang. I Korintus 11:27 Paulus menjelaskan bahwa dalam perjamuan, cara yang tidak layak. Hal ini menunjukkan ketidakhormatan orang tersebut dan pengabaian untuk bertobat. Mereka yang mengikuti Perjamuan Kudus dengan cara demikian berdosa terhadap tubuh dan darah Tuhan (Stamps, 1984, p. 1900). Sikap tidak layak dalam mengikuti Perjamuan Kudus menjadi indikator bahwa pengorbanan Yesus Kristus di atas kayu salib hanya sampai pada ranah kognitif dan belum membawa ke arah perubahan hidup. Jelas bahwa Perjamuan Kudus bukan hanya sekadar aturan buatan manusia atau hasil ciptaan organisasi gereja.

Berikut adalah beberapa hal yang dapat dilakukan untuk merayakan Perjamuan Kudus. Pertama adalah merendahkan diri dan sadar akan dosa. Kedua, memohon dengan iman yang jujur di hadapan Allah. Ketiga, melakukan segala kebijakan dengan jujur, taat dan sesuai dengan perintah Tuhan. Selanjutnya syarat mengenai batasan usia peserta Perjamuan Kudus, tidak ada referensi batas bawah usia mengikuti Perjamuan Kudus. Akan tetapi mengacu dari I Korintus 11:27, disarankan agar orang-orang dalam usia dewasa yang mengikuti Perjamuan Kudus. Usia dewasa dianggap mampu mengerti setiap tindakan yang dibuat. Usia dewasa dianggap mampu mengerti makna dari Perjamuan Kudus. Lebih dari itu mereka telah mengenal Yesus sebagai Tuhan dan Juruselamat.

Secara pedagogis, sakramen Perjamuan $\mathrm{Ku}-$ dus membimbing orang percaya untuk melakukan introspeksi diri. Mary dan Darmawan (2018) menjelaskan bahwa salah satu penekanan dalam pendidikan Kristen adalah aspek afektif. Ketika dilaksanakan sakramen Perjamuan Kudus, setiap orang percaya diminta terlebih dahulu untuk melakukan introspeksi diri. Melalui introspeksi diri, orang percaya dibim- 
bing untuk menyadari dosanya dan anugerah Allah yang besar. Dalam hal ini aspek afektif dalam pendidikan dilaksanakan. Dengan demikian, sakramen Perjamuan Kudus berperan penting dalam pendidikan dalam konteks gereja.

\section{KESIMPULAN}

Perjamuan Paskah dalam Perjanjian Lama menjadi pola awal Perjamuan Kudus. Makna keselamatan begitu besar dalam perayaan Paskah ini. Perjamuan Paskah ini kemudian pada masa Perjanjian Baru dilakukan oleh Yesus dengan mengadakan perjamuan bersama dengan para murid-Nya. Yesus kemudian menggunakan roti dan anggur yang melambangkan pengorbanan-Nya bagi manusia. Jika dalam Perjanjian Lama, Perjamuan Paskah merupakan peringatan akan karya pembebasan Allah, maka dalam Perjanjian Baru, Perjamuan Paskah menjadi pengingat pengorbanan Kristus bagi manusia. Dalam perkembangannya, perjamuan ini disebut sebagai Perjamuan Kudus.

Berdasarkan pembagian waktu maka terdapat

\section{DAFTAR RUJUKAN}

Abineno, C. H. (1981). Pemberitaan Firman Allah pada Hari Khusus. Jakarta: BPK Gunung Mulia.

Abineno, C. H. (1990). Perjamuan Malam Menurut Reformator. Jakarta: BPK Gunung Mulia.

Barth, C., \& Frommel, M. C. B. (1998). Teologi Perjanjian Lama Jilid 1. Jakarta: BPK Gunung Mulia.

Bavink, F. L. (1990). Sejarah Kerajaan Allah 1. Jakarta: BPK Gunung Mulia.

Brill, W. J. (2003). Dasar Yang Teguh. Bandung: Kalam Hidup.

Darmawan, I. P. A. (2017). Murid yang Memuridkan. In Melaksanakan Amanat Agung di Abad 21. Ungaran: Sekolah Tinggi Teologi Simpson.

Darmawan, I. P. A. (2019a). Jadikanlah Murid: Tugas Pemuridan Gereja Menurut Matius 28:18-20.

Evangelikal: Jurnal Teologi Injili Dan Pembinaan Warga Jemaat, 3(2), 144-153. tiga makna Perjamuan Kudus yaitu makna menyangkut masa lalu, kini dan yang akan datang. Makna masa lalu berarti bahwa Perjamuan Kudus merupakan peringatan pengorbanan Kristus bagi orang percaya. Masa kini berarti bahwa Perjamuan Kudus memiliki makna keikutsertaan menikmati keuntungan kematian Kristus serta persekutuan dengan anggota tubuh Kristus, bahkan Kristus sendiri. Makna masa yang akan datang berarti bahwa Perjamuan Kudus menjadi jaminan menikmati Kerajaan Sorga dan perjamuan agung di masa yang akan datang. Perjamuan Kudus merupakan perwujudan pengharapan akan kedatangan-Nya kembali. Kristus Yesus adalah pengharapan yang pasti. Secara praktis, Perjamuan Kudus mengingatkan tentang pentingnya persekutuan dengan sesama anggota tubuh Kristus. Persekutuan ber-fungsi membawa jemaat menuju kesatuan sebagai anggota tubuh Kristus dan dalam persekutuan tersebut, jemaat dibawa untuk mengingat karya Kristus di kayu Salib melalui Perjamuan Kudus.

\section{Retrieved}

from https://journal.sttsimpson.ac.id/index.php/EJ TI/article/view/138

Darmawan, I. P. A. (2019b). Pembelajaran Memorisasi Dalam Ulangan 6:6-9. EPIGRAPHE: Jurnal Teologi Dan Pelayanan Kristiani, 3(1), 21-27. https://doi.org/10.33991/epigraphe.v3i1.50

Darmawan, I. P. A., \& Asriningsari, A. (2018). Buku Ajar Penulisan Karya Ilmiah. Ungaran: Sekolah Tinggi Teologi Simpson.

Groome, T. H. (2011). Christian Religious Education. Jakarta: BPK Gunung Mulia.

Guthrie, D. (2007). 1 Korintus. In Tafsiran Alkitab Masa Kini 3: Matius-Wahyu. Jakarta: Yayasan Komunikasi Bina Kasih.

Hadiwijono, H. (2001). Inilah Sahadatku. Jakarta: BPK Gunung Mulia.

Hadiwijono, H. (2010). Iman Kristen. Jakarta: BPK 
Gunung Mulia.

Hamzah, A. (2019). Metode Penelitian Kualitatif. Malang: Literasi Nusantara.

Heyer, C. J. D. (1997). Perjamuan Tuhan. Jakarta: BPK Gunung Mulia.

Hodge, A. A. (1958). Commentary on the Confession of Faith. London: Banner of Truth.

Indonesia, K. W. G. (1996). Iman Katolik. Yogyakarta: Kanisius.

Kadarmanto, M. (2018). Reaffirmasi Sola Scriptura: Mendidik Dalam Wawasan Alkitabiah. https://doi.org/10.17605/osf.io/jhr8e

Katarina, K., \& Darmawan, I. P. A. (2019). Implikasi Alkitab dalam Formasi Rohani pada Era Reformasi Gereja. EPIGRAPHE: Jurnal Teologi Dan Pelayanan Kristiani, 3(2), 8193.

https://doi.org/10.33991/epigraphe.v3i2.85

Martasudjita, E. (2003). Sakramen-sakramen Gereja:

Tinjauan Teologis, Liturgis dan Pastoral.

Yogyakarta: Kanisius.

Mary, E., \& Darmawan, I. P. A. (2018). Guru Agama

Kristen Yang Profesional. Salatiga: Satya Wacana University Press.

Mawikere, M. C. S. (2017). Perbandingan Teologi Keselamatan Antara Katolik Dan Protestan Sebelum Dan Sesudah Gerakan Reformasi. Evangelikal: Jurnal Teologi Injili Dan Pembinaan Warga Jemaat, 1(1), 1-18. Retrieved from https://journal.sttsimpson.ac.id/index.php/EJ $\mathrm{TI} /$ article/view/52

Naat, D. E. (2020). Tinjauan Teologis-Dogmatis Tentang Sakramen Dalam Pelayanan Gerejawi. Jurnal Teologi Pengarah, 2(1), 114.

https://doi.org/10.36270/pengarah.v2i1.18

Niftrik, G. C. van, \& Boland, B. J. (1978). Dogmatika Masa Kini. Jakarta: BPK Gunung Mulia.

Objantoro, E. (2017). Sejarah dan Pemikiran Kaum Injili di Tengah-tengah Perubahan dan Tantangan Zaman. Evangelikal: Jurnal Teologi Injili Dan Pembinaan Warga
Jemaat, 1(2), 129-138. Retrieved from https://journal.sttsimpson.ac.id/index.php/EJ $\mathrm{TI} /$ article/view/77

Pakpahan, B. J. (2013). EKARISTI DAN REKONSILIASI Sebuah Upaya Mencari Eklesiologi Gereja-gereja Pasca Konflik. Gema Teologi, 37(1). Retrieved from http://journal-

theo.ukdw.ac.id/index.php/gema/article/vie w/160

Pakpahan, B. J. (2014). Analisis Kritis Liturgi Perjamuan Kudus Huria Kristen Batak Protestan. Indonesian Journal of Theology, 2(1), 42-64.

Panjaitan, B. J. (2013). Teologi Ingatan Sebagai Dasar Rekonsiliasi Dalam Konflik. Diskursus - Jurnal Filsafat Dan Teologi STF Driyarkara, 12(2), 253-277. Retrieved from https://journal.driyarkara.ac.id/index.php/dis kursus/article/view/107

Pattiasina, S. M. O. (2019). Perhadliran dalam Sakramen Perjamuan Kudus di Gereja Protestan Maluku. BIA': Jurnal Teologi Dan Pendidikan Kristen Kontekstual, 2(2), 179192. https://doi.org/10.34307/b.v2i2.107

Prasetya, L. (1999). Panduan untuk Calon Baptis Dewasa. Yogyakarta: Kanisius.

Purwanto, N. (2000). Ilmu Pendidikan Teroritis dan Praktis. Bandung: Rosdakarya. Retrieved from https://rosda.co.id/pendidikankeguruan/370-ilmu-pendidikan-teroritis-danpraktis.html

Putry, D., Darmawan, I. P., \& Sujoko, E. (2020). Implementing Total Quality Management in Christian Lesson. Proceedings of the Third Workshop on Multidisciplinary and Its Applications, WMA-3 2019, 11-14 December 2019, Medan, Indonesia. Retrieved from https://eudl.eu/doi/10.4108/eai.11-122019.2290810

Rantesalu, S. B. (2018). Kompetensi Pedagogik Menurut Analisis Ulangan 6:7-9 dengan Pendekatan Hermeneutik Schleiermacher. 
BIA': Jurnal Teologi Dan Pendidikan

Kristen Kontekstual, 1(2), 153-163. https://doi.org/10.34307/b.v1i2.14

Rizky, R. (2016, September 8). Konsep Dasar Pedagogik Pendidikan . Retrieved January 24, 2021, from Kompasiana.com website: https://www.kompasiana.com/hfkjejhgjehgf kjjugyf/57f8f1c1b37a61f313f1fa62/konsepdasar-pedagogik-pendidikan?page=all

Roti Paskah. (2012, April). Manna Sorgawi.

Rumbi, F. P. (2019). Manajemen Konflik Dalam Gereja Mula-Mula: Tafsir Kisah Para Rasul 2:41-47. Evangelikal: Jurnal Teologi Injili Dan Pembinaan Warga Jemaat, 3(1), 9-20. Retrieved

from https://journal.sttsimpson.ac.id/index.php/EJ TI/article/view/114

Santoso, A. (2011). Logos: Tata Bahasa Yunani Koine. Bandung: Bina Media Informasi.

Santoso, A. (2018). Salib: Pembenaran di Dalam Kristus. Majalah Sinode GIA.

Silitonga, A. R., Natonis, P., \& Darmawan, I. P. A. (2020). Implikasi Konsep Yesus Pengudus Menurut A.B. Simpson Bagi Orang Kristen Masa Kini. KAPATA: Jurnal Teologi Dan Pendidikan Kristen, 1(2), 89-98. Retrieved from http://jurnalsttba.ac.id/index.php/KJTPK/article/view/12

Simpson, A. B. (1984). The Four-fold Gospel (C. Publications, Ed.). Camp Hill: Christian Publications.

Smith, K. G. (2016). Writing and Research: A Guide for Theological Students. Cumbria: Langham Global Library.

Soedarmo, R. (1989). Ikhtisar Dogmatika. Jakarta: BPK Gunung Mulia.
Stamps, D. C. (1984). Catatan Penelitian dan Artikel Alkitab. In Alkitab Penuntun Hidup Berkelimpahan. Malang: Gandum Mas.

Susanti, A. (2017). Relevansi Finalitas Kristus Di Tengah-Tengah Arus Pluralisme Dan Pluralitas Masyarakat Indonesia. Evangelikal: Jurnal Teologi Injili Dan Pembinaan Warga Jemaat, 1(1), 85-102. Retrieved from https://journal.sttsimpson.ac.id/index.php/EJ TI/article/view/65

Tety, T., \& Wiraatmadja, S. (2017). Prinsip-Prinsip Filsafat Pendidikan Kristen. Evangelikal: Jurnal Teologi Injili Dan Pembinaan Warga Jemaat, 1(1), 55-60. Retrieved from https://journal.sttsimpson.ac.id/index.php/EJ TI/article/view/56

Tuela, A. (2014). Perjamuan Kudus Menurut Yohanes Calvin Dan Pemahaman Jemaat Gmim "Kanaan” Ranotana Weru Tentang Perjamuan Kudus. Tumou Tou (Journal Ajaran Kristianitas, Ajaran Dan Kemasyarakatan), 1(2), 127-140. Retrieved from

http://156.67.221.18/index.php/TT/article/vi ew/20

Williamson, G. I. (2004). Pengakuan Iman Westminster: untuk kelas penelaahan. Surabaya: Momentum.

Zaluchu, S. E. (2020). Strategi Penelitian Kualitatif dan Kuantitatif Di Dalam Penelitian Agama. Evangelikal: Jurnal Teologi Injili Dan Pembinaan Warga Jemaat, 4(1), 28-38. https://doi.org/https://doi.org/10.46445/ejti.v $4 \mathrm{i} 1.167$ 